\title{
Tallage-at-Will in Later Medieval England*
}

\section{Mark Bailey}

Tallage-at-will was a seigniorial tax on unfree tenants and hereditary serfs in medieval England, and one of the two main tests of villeinage under the common law. Contemporary lawyers asserted that lords could impose servile tallage on their villeins whenever they wished and at whatever level they chose. Consequently, many historians have argued that tallage-at-will was an onerous and malleable incident, reflecting the arbitrary, burdensome and exploitative character of villeinage in England. Postan argued that all the dues associated with villeinage 'were overshadowed by tallage, which was frequently a heavy annual tax, almost as heavy as the rent itself'. ${ }^{1}$ T.W. Page observed that lords 'held firmly to the principle that, if they chose, they could tallage the villeins to the whole extent of their possessions', while Hilton regarded it as a 'monetary facet of lordly power', an 'arbitrary' incident which served as one of the 'coercive sanctions' used to transfer peasant surpluses to their lords. ${ }^{2}$ Martin argued that its size and frequency was such that it 'played a crucial part in determining both tenants' standard of living and their ability to invest in land and other means of production, so that middling peasants were thereby prevented from accumulating surplus'. ${ }^{3}$ H.S. Bennett concluded 'there can be no doubt that tallage-at-will was oppressive...a hated sign of [villein] inferiority'. ${ }^{4}$

Thus tallage-at-will is presented as unpredictable, demanding and demeaning. Yet these strident judgements are not based on careful and systematic research into manorial documents, where its operation on the ground is recorded. Indeed, no single study of its history has yet been written, even though the other main test of villeinage, merchet, and lesser servile incidents such as chevage and leyrwite have all been subject to scrutiny. ${ }^{5}$ It is treated fleetingly and anecdotally in the case

\footnotetext{
* John Hatcher and Steve Rigby offered helpful comments on an early version of this article, which also benefited from comments at the Anglo-American Medieval Economic History Conference held at Stirling in 2016.

${ }^{1}$ M. M. Postan, 'Medieval Agrarian Society in its Prime: England', in M. M. Postan, ed., The Cambridge Economic History of Europe, I: The Middle Ages (Cambridge, second edition, 1971), pp. 603-4; M. M. Postan, The Medieval Economy and Society (London, 1972), p. 139; see also B. A. Hanawalt, 'Peasant Resistance to Royal and Seigniorial Impositions' in F. X. Newman, ed., Social Unrest in the Late Middle Ages (New York, 1986), pp. 24-5, 33-4.

2 T.W. Page, The End of Villeinage in England, American Economic Association, 99 (1900), p. 17; R. H. Hilton, A Medieval Society: the West Midlands in the Later Middle Ages, pp. 144-7; R. H. Hilton, The English Peasantry in the Later Middle Ages (Oxford, 1973), pp. 199, 237; R. H. Hilton, Class Conflict and the Crisis of Feudalism (second edition, London, 1990), pp. 50-1.

${ }^{3}$ J. E. Martin, Feudalism to Capitalism. Peasant and Landlord in English Agrarian Development (London, 1986), pp. 42-4.

${ }^{4}$ H.E. Bennett, Life on the English manor. A Study of Peasant Conditions 1150-1400 (Cambridge, 1938), pp. 139, 141.

${ }^{5}$ The best single treatment of tallage is N. Neilson, 'Customary rents', in P. Vinogradoff, ed., Oxford Studies in Social and Legal History, Volume II (Oxford, 1910), pp. 90-5, although the discussion is limited to a handful of monastic estates. For examples of other servile incidents, J. Scammell, 'Freedom and Marriage in England', Economic History Review, $2^{\text {nd }}$ Series, xxvii (1974), pp. 523-37; E. Searle, 'Seigniorial Control of Women's Marriage: the Antecedents and Function of Merchet in England', Past and Present, Ixxxii (1979), pp. 3-43; P. Brand and P. R. Hyams, 'Seigneurial Control of Women's Marriage', Past and Present, xcix (1983), pp. 123-33; J. M. Bennett, 'Writing Fornication: Medieval Leyrwite and its Historians', Transactions of the Royal Historical Society, sixth series, xiii (2003), pp. 131-62; T. North, 'Legerwite in the Thirteenth and Fourteenth Centuries',
} 
studies of individual estates and manors, prompting Hilton to observe that 'precise details...are difficult to come by'. ${ }^{6}$ This is due to the nature of references to tallage in manorial sources, which are either elusive or terse or have to be pieced together from a range and number of documents. Entries in manorial accounts tend to be perfunctory; other categories of manorial documents (court rolls and surveys) seldom reveal much detail about its underlying mechanics; tracking changes over time require the survival of a good series of accounts; and explaining temporal changes is dependent upon the survival of a court roll series offering unusually detailed information.

Thus we know surprisingly little about the form and function of tallage-at-will, because its operation is hard to reconstruct from the sources. The task is essential, however, if we are to establish whether the legal theory matched practical applications on the ground. This article offers the first general survey of tallage-at-will, exploring how tallage actually operated at its peak in c.1300; the sums paid and their frequency; how individual contributions were assessed and their affordability; and the main changes over time, particularly decline in the late fourteenth century. It reveals a sizeable gap between the legal theory and manorial practice: by c.1300 the frequency and level of tallage had become largely fixed, individual contributions were codified and capped, and it was not even levied on many small manors. Custom influenced its operation to a considerable degree. Consequently, it was not an unpredictable and onerous drain upon the resources of English villeins, although it was undoubtedly irksome and socially stigmatic. Furthermore, the differences between the villein's tallage and the freeman's aid were less clear cut than medieval lawyers would have us believe. Tallage-at-will, no less than villeinage in England, was more complex, moderate and heterogeneous than asserted in medieval legal doctrine.

1

The noun tallage (tallagium), also known as aid (auxilium), was used loosely to describe various forms of taxation in medieval England, but essentially it referred to a prerogative tax levied by lords upon their dependents. Its early history is obscure, although from an early date it existed in a variety of forms and was not exclusively applied to the servile population. ${ }^{7}$ Stephenson argued that it first became an imposition upon the peasantry soon after the Norman Conquest, establishing the principle that lordship of a manor conferred the right to tallage, but at this stage it constituted part of a vague fringe of peasant obligations. ${ }^{8}$ By the late twelfth century these forms had become less vague and more settled: the king levied aid upon royal boroughs, the royal demesne and his tenantsin-chief; the tenants-in-chief levied aid upon their vassals; and landlords also exacted it from their own peasants. ${ }^{9}$ The frequency and timing of these levies were not fixed in the twelfth century, but were based upon the lord's judgement of when reasonable grounds existed and what he could get away with. The king, for example, might claim a national emergency and appeal to the obligation of

Past and Present, cxi (1986), pp. 3-16; E. D. Jones, 'The Medieval Leyrwite: a Historical Note upon Fornication', ante, cvii (1992), pp. 945-53; R.E. Latham, 'Minor Enigmas from Medieval Records', ante, Ixxvi (1961), pp. 63349.

${ }^{6}$ Hilton, English Peasantry, p. 237.

${ }^{7}$ F. Pollock and F. W. Maitland, History of English Law, volume I (second edition, Cambridge, 1963), p. 394.

${ }^{8}$ C. Stephenson, 'The Seignorial Tallage in England', in Melanges Offerts a Henri Pirenne (Brussels, 1926), pp. 470-3; P. R. Hymans, King, Lords and Peasants in Medieval England (Oxford, 1980), pp. 191-2.

${ }^{9}$ C. Stephenson, Borough and Town. A Study of Urban Origins in England (Cambridge Mass., 1933), pp. 162-5, 170; R.S. Hoyt, The Royal Demesne in English Constitutional History (Ithaca, New York, 1950), pp. 108, 113, 121; M. Howell, Regalian Right in Medieval England (London, 1962), pp. 122-3, 136; G. L. Harriss, King, Parliament and Public Finance in Medieval England to 1369 (Oxford, 1975), pp. 12-16. 
the realm to assist him with financial aid, while in c.1200 St Swithun's priory, Winchester (Hampshire), justified its call for aid from all of its vassals and its peasants (free and unfree) by its acute indebtedness. ${ }^{10}$

From the 1220s lawyers and administrators began to distinguish even more carefully between the types of tallage rendered by the peasantry. As part of a contemporary determination to sharpen the distinction between the free and the unfree, a line was drawn between the exaction from the freeman, which had to be justified and taken for the common good, and the exaction from the villein, which did not have to be justified and was taken for the lord's use. A freeman owned his goods under the common law, so any seigniorial aid required some form of consent and justification: in contrast, the villein's chattels belonged to his lord, so it follows that the lord could therefore use the device of aid to seize and tax them at any time and in any quantity. ${ }^{11}$ By the 1240 s tallage-at-will had become recognisable as a seigniorial tallage upon villeins, and was now established as one of the two most convincing legal tests of villeinage under the common law. ${ }^{12}$ Subsequently, manorial documents were often at pains to record that villein land was liable for tallage 'at the will of the lord' (ad voluntatem domini) to remove any doubt about its status. ${ }^{13}$ Legal cases usually added that it was also charged 'high and low', meaning that the lord could arbitrarily vary the sum demanded. Thus in 1350 the abbot of Vale Royal claimed the right 'to tallage his villeins high and low (alto et basso) at will, and by them to have all the profit and progeny of those same villeins'. ${ }^{14}$

So by the mid-thirteenth century the various types of tallage, and the occasions upon which they were levied, were more precisely known, although contemporary writers continued to use the noun as a blanket term for all forms of royal taxation. ${ }^{15}$ Royal tallages were levied about one year in three, and on these occasions tenants-in-chief could turn to their dependent lords and freemen for aid. ${ }^{16}$ Landlords also imposed aids upon their free tenants on special occasions, such as upon the former's elevation to knighthood, the marriage of their eldest daughter or when serving the king overseas. ${ }^{17}$ Tallage-at-will was a matter for the individual lord to determine upon his villeins. The distinction between general tallage and tallage-at-will was further reinforced by contemporary social conventions, which depicted the aids of lords and freemen as 'gracious', consensual and negotiable

\footnotetext{
${ }^{10}$ Harriss, King, Parliament, pp. 40-1; Pollock and Maitland, English Law, I, p. 350.

${ }^{11}$ Hyams, King, Lords and Peasants, pp. 190-2.

${ }^{12}$ Hyams, King, Lords and Peasants, pp. 191-3, 241, 267. See also A. E. Levett, Studies in Manorial History (Oxford, 1938), p. 193; F. M. Page, The Estates of Crowland Abbey (Cambridge, 1934), pp. 131-2; C. Dyer, 'The Ineffectiveness of Lordship in England 1200-1400', in C. Dyer, P. Coss and C. Wickham, eds., Rodney Hilton's Middle Ages (Past and Present Supplement, 2007), pp. 73-4; E. B. Fryde, Peasants and Landlords in Later Medieval England (Stroud, 1996), pp. 23-4.

${ }^{13}$ See, for example, the fixed communal tallage paid by the bondmen of Walcot in 1296-7 pro voluntate domini, in S. Raban, ed., The White Book of Peterborough, Northamptonshire Record Society, XLI (2001), p. 91; also O. Hassall and J. Beauroy, Lordship and Landscape in Norfolk, 1250-1350: the Early Records of Holkham British Academy, Records of Social and Economic History, New Series, xx (1993), p. 106; Levett, Manorial History, p. 193. For local examples, see, for example, A. E. Wilson, ed., Custumals of the Manors of Laughton, Willingdon and Goring, Sussex Record Society, Ix (1961), pp. 50-1, 62, 65, and A. H. Denney, The Sibton Abbey estates. Select Documents 1325-1509, Suffolk Records Society, I (1960), pp. 49-50.

${ }^{14} \mathrm{~J}$. Brownhill, ed., The Ledger Book of Vale Royal Abbey, The Record Society for Lancashire and Cheshire, Ixviii, p. 134; Page, End of Villeinage, pp. 17-18.

${ }^{15}$ Hyams, King, Lords and Peasants, p. 192 n. 39; W. Scase, Literature and Complaint in England 1272-1553 (Oxford, 2007), pp. 17-18 reinforces the sense that 'tallage' covered all manner of taxes.

${ }^{16}$ S. K. Mitchell, Studies in Taxation under John and Henry III (New York, 1914), pp. 340, 351; Hoyt, Royal

Demesne, p. 121; Howell, Regalian Right, pp. 124-5.

17 Pollock and Maitland, History of English Law, I, p. 349; Mitchell, Studies in Taxation, 346-7, 349-50.
} 
(auxilium bone voluntate), whereas the servile tallage of the villein was imposed at the will of the lord without the need for justification or consent, and so was potentially unpredictable in both frequency and quantum. ${ }^{18}$

From the 1220s royal writs increasingly sought to distinguish the tallage of rustics from the aid of knights and freemen, and Scase suggests that by c.1300 the word 'aid' had come to imply in popular usage a moderate and tolerable tax, whereas tallage was now associated with something more severe, forceful and oppressive. ${ }^{19}$ No such distinction between free 'aid' and servile 'tallage' is apparent in the wide array of phrases used to describe the latter in manorial documents, however, where the words auxilium and tallagium appear frequently and interchangeably. ${ }^{20}$ Tallage is used as both a noun (tallagium bondorum, tallagium custumariorum, and tallagium consuetudinariorum) and a verb (talliari ad voluntatem domini, talliabitur), while aid is most frequently used as a noun (auxilium consuetum, auxilium bondorum, auxilium custumali de bondis, auxilium pro voluntate domini and auxilium omnium consuetudinariorum). References to tallage-at-will within the surviving Hundred Rolls for Warwickshire from 1279 used both 'tallage' and 'aid', sometimes interchangeably. Thus $12 \%$ of the manors in Stoneleigh Hundred used 'tallage' and $88 \%$ 'aid', whereas in Kineton Hundred 65\% used 'tallage', 30\% 'aid', and 5\% used both. ${ }^{21}$ The choice of one or the other did not signify any differences in practice or meaning, simply local preference. Hence the clear social and legal distinction between a servile tallage and free aid was not evident on the ground.

Five general points can be confidently made about the ways in which tallage-at-will operated around 1300 at the peak of its maturity. The first is that it existed in two forms: a regular, usually annual, charge and an occasional charge widely known as 'recognition'. The latter was a payment from all villeins upon the accession of a new lord of the manor, which thus underlined in a very public manner their subjugation to the lord. ${ }^{22}$ Recognition and annual tallage were often mutually exclusive, i.e. an estate charged one or the other but not both, and so recognition was effectively an infrequent version of tallage. ${ }^{23}$ In East Anglia smaller manors held by lay gentry landlords often

18 S. K. Mitchell, Taxation in Medieval England (Yale, 1951), pp. 236-7; Hyams, King, Lords and Peasants, pp. 187, 192-3; P. Vinogradoff, Villeinage in England (Oxford, 1892), pp. 162-3; Hilton, English Peasantry, p. 238; Fryde, Peasants and Landlords, p. 24.

${ }^{19}$ Hyams, Kings, Lords and Peasants, p. 192; Scase, Literature and Complaint, pp. 18-21, 26; Howell, Regalian Right, pp. 132-3, 135.

${ }^{20}$ Hoyt, Royal Demesne, pp. 110-11; Howell, Regalian Right, pp. 130-1.

${ }^{21}$ T. John, ed., The Warwickshire Hundred Rolls of 1279-80: Stoneleigh and Kineton Hundreds, British Academy, Records of Social and Economic History, New Series, xix (1992). Manors are not explicitly named as such within the rolls, so a manor is defined as a landholding held either for parts of a knight's fee or in perpetual alms, and possessing a dependent peasantry. The calculation excludes those manors which do not possess villeins, i.e. which just contained free tenants (such as Whoterley, Coundon, Radford and two in Fenny Compton, John, Warwickshire, pp. 123-32, 257-8), and also those manors for which only a fragment of the original entry survives (such as Kingston, John, Warwickshire, p. 250). The percentages are based on those manors whose villeins are explicitly described as liable for tallage.

22 Vinogradoff, Villeinage in England, p. 348; Howell, Regalian Right, pp. 136-40; M. Bailey, The Decline of Serfdom in Late-Medieval England (Woodbridge, 2014), pp. 47-8; J. Birrell, 'Manorial Custumals Reconsidered', Past and Present, ccxxiv (2014), p. 27.

${ }^{23}$ On a few estates the noun 'recognition' had different meanings. It was used to describe an entry fine payable upon admission to customary land on some estates: I. Kershaw, D. M. Smith, eds., The Bolton Priory Compotus, 1286-1325: Together with a Priory Account Roll for 1377-1378, Yorkshire Archaeological Society Record Series, cliv (2001), pp. 27-8; on others, it was used to describe a payment to be absent from the manor (usually known as 'chevage'), Raban, White Book, p. 159. 
levied recognition but not annual tallage. This was the case on the small Suffolk manors of the earl of Suffolk, on the small manor of Wimbotsham (Norfolk) and on the contiguous but separate manors of Walsham-le-Willows and Walsham High Hall (Suffolk). ${ }^{24}$ Recognition was especially common on ecclesiastical estates. ${ }^{25}$ The abbot of Bury St Edmunds and the bishop of Ely charged recognition across the whole of their estates upon their election, but not annual tallage, and the tenants of Salton (Northumberland) on the estate of Hexham priory rendered '10 marks of silver towards the purchase of a palfray for the lord prior when he is newly elected' ${ }^{26}$ The sums charged were variable originally, but many had become rounded and standardized by the early fourteenth century. In most cases where recognition was the only form of tallage, the payment was collected through the manorial court rather than through the account.

A handful of estates charged both recognition and an annual tallage. These were exclusively ecclesiastical landlords, such as Crowland abbey, Ogbourne priory, Westminster abbey, and the bishopric of Worcester. ${ }^{27}$ The Hampshire manors of Beaulieu abbey paid recognition but not tallage in 1269-70, although the abbey's manors outside the county paid both. ${ }^{28}$ There is no obvious pattern to the relative size of recognition and tallage payments where both were due. Recognition was merely one fifth the size of tallage at Great Faringdon (Berkshire), yet it was equal at Shilton (Oxfordshire), and over twice the size at Coxwell (Berkshire). At Wellingborough

(Northamptonshire), on the Crowland abbey estate, recognition was marginally higher than tallage. ${ }^{29}$

The second generalisation is that the frequency of tallage had become largely fixed and predictable in the vast majority of places. In many places it had become an annual charge paid in a single instalment on a set feast day each year, usually at Michaelmas according to Bennett. ${ }^{30}$ Unfortunately, the collection date is not often recorded in manorial documents, although Michaelmas often features when it is. ${ }^{31} \mathrm{~A}$ few manors had other set days for collection: Martinmas

\footnotetext{
${ }^{24}$ In 1371 the 'customars' of Ufford (Suffolk) manor paid 5s. on the accession of the new earl of Suffolk, and those on other proximate manors paid similar sums: Segho (20s.), Windermill (12d.), and Woodhall (13s. 4d.), S[uffolk] R[ecord] O[ffice] Ipswich, HD1538/394, court held March 1370; N[orfolk] R[ecord] O[ffice], Hare 4238, court held February 1353; Bailey, Decline of Serfdom, p. 107, 115-16.

${ }^{25}$ Bennett, Life on the Manor, p. 142; Levett, Manorial History, p. 255.

${ }^{26}$ For Bury abbey, see infra pp. 00-0; E. Miller, The Abbey and Bishopric of Ely (Cambridge, 1951), p. 140 and TNA SC6/995/14; R. H. Britnell, C. Etty and A. King, eds., The Black Book of Hexham. A Northern Monastic Estate in 1379, Hexham Local History Society (2011), p. 140.

${ }^{27}$ See F. M. Page, ed., Wellingborough Manorial Accounts AD 1258 to 1323, Northamptonshire Records Society, viii (1936), pp. xxiii, 117; B. Harvey, The Estates of Westminster Abbey in the Later Middle Ages (Oxford, 1975), p. 224; C. Dyer, Lords and Peasants in a Changing Society (Cambridge, 1980), p. 290. The Ogbourne example is documented in Table 3.

${ }^{28}$ S. F. Hockey, ed., The Account Book of Beaulieu Abbey, Camden Society, $4^{\text {th }}$ Series, xvi (1975), pp. 108-9, 1145, 120-1, 130-1 for the four Hampshire manors of Burgate, Soberton, Colbury and Holbury; and p. 59 for Shilton (Oxon), p. 64 for Little Faringdon (Oxon), p. 69 for Inglesham (Wiltshire), p. 85 for Great Faringdon (Berks.), p. 87 for Westbrook (Berkshire), and pp. 89-90 for Coxwell (Berkshire)

${ }^{29}$ Annual tallage was $£ 15$ in both $1304-5$ and $1314-5$, and recognition was $£ 16$ in the former and $£ 18$ in the latter, Page, Wellingborough, pp. 89, 117.

${ }^{30}$ Bennett, Life on the Manor, p. 141.

${ }^{31}$ For example, on the Gloucester abbey estates: W.H. Hart, ed., History and Cartulary of the Monastery of St Peter, Gloucester, volume III, Rolls Series (1867), pp. 117, 119, 129. See also Neilson, 'Customary Rents', pp. 90-3. For Michaelmas payments at Norton (Herts.), Levett, Manorial History, p. 334; for Clapton (NHants), E. King, ed., Estate Records of the Hotot family, Northamptonshire Record Society, xxxii (1983), p. 23; and Thorley and Wellow (Isle of Wight), TNA SC6/985/9, mm. 4 and 5. At Sevenhampton the level of tallage was confirmed in the court immediately before Michaelmas, and then recorded within the manorial account for that agrarian year. Hence 60 s. aid is recorded as payable in the court held $24^{\text {th }}$ September 1276 , and the sum is
} 
at Weedon Bec (Buckinghamshire), Mere (Wiltshire) and a number of manors on the Isle of Wight, while villeins at Ruislip (Middlesex) paid on Hockday, on St Bartholomew's day at Wellingborough (Northamptonshire), and on All Saints day at Hurdwick and Werrington (Devon). ${ }^{32}$ Tallage owed by villeins on manors held by the king was not an annual charge, but occurred 'whenever the king tallages his manors' ${ }^{33}$ The linking of the frequency of tallage to the king's aids on manors of the royal demesne, and the establishment of a set feast day for collecting tallage almost everywhere, underline the powerful influence of custom on its operation.

Third, the level of tallage had become predictable and largely fixed, rather than variable. ${ }^{34}$ In many parts of northern England it was an annual payment of a rounded and fixed sum. ${ }^{35}$ After c.1250 fixed tallage was the rule on both the abbatial and conventual manors of Westminster abbey, and the sums paid annually on the latter's estate were so low and unchanging that Harvey deduced they had been fixed since 'the distant past': for example, in the late thirteenth century a 40s. tallage was due every year at Stevenage (Hertfordshire). ${ }^{36}$ Likewise regular sums were levied annually on manors of the earls of Devon, and rounded sums were paid on the earl of Norfolk's estate, such as the $£ 96 \mathrm{~s}$. 8d. per annum at Bungay (Suffolk) and $£ 13$ 6s. 8d. at Oakham (Rutland). ${ }^{37} A$ long run of accounts invariably reveal that sums did not much vary from year to year, which proves that tallage was not arbitrary, as the examples of Wellingborough (Northamptonshire) and Hollesley (Suffolk) show:

TABLES 1 and 2 about here.

All the evidence from manorial sources around 1300 proves that the frequency and the amount of tallage was more-or-less fixed, and 'no longer literally at the will of the lord' ${ }^{38}$ Page's speculative claim that 'the sums drawn from the villeins as tallage differed considerably from year to year', and Hilton's that 'arbitrary tallage was the most typical', are incorrect. ${ }^{39}$ I have yet to discover a single example of tallage-at-will being imposed as an exceptional levy in timing and/or amount.

subsequently recorded in the manorial account for 1275-6, R.B. Pugh, ed., Court Rolls of the Wiltshire Manors of Adam de Stratton, Wiltshire Record Society, xxix (1970), p. 33; M.W. Farr, ed., Accounts and Surveys of the Wiltshire lands of Adam de Stratton, Wiltshire Archaeological and Natural History Society, Record Branch, xiv (1958), p. 71.

32 See Martinmas payments on the Isle of Wight manors of Bowcombe, Newton and Penne, TNA SC6/985/15, mm. 4, 6, 7. Chibnall, Compotus Rolls, pp. 98 (Ruislip) and 116 (Weedon); L. M. Midgley, ed., Ministers' Accounts of the Earldom of Cornwall 1296-1297 volume I, Camden Society, $3^{\text {rd }}$ series, Ixvi (1942), p. 55 (Mere); Page, Wellingborough, pp. 89, 117; H. P. R. Finberg, Tavistock abbey (Cambridge, 1951), p. 78 (Hurdwick, Werrington).

${ }^{33}$ This quote is taken from the royal demesne manor of Alrewas (Staffordshire), J. Birrell and D. Hutchinson, 'An Alrewas Rental of 1341', Staffordshire Record Society, 4th series, xx (2000), p. 79.

${ }^{34}$ C. Dyer, 'Villeins, Bondsmen, Neifs and Serfs: New Serfdom in England, c.1200-c.1600', in P. Freedman and M. Bourin, eds., Forms of Servitude in Northern and Central Europe. Decline, Resistance and Expansion (Turnhout, 2005), p. 426.

${ }^{35}$ E. Miller, 'Social Structure: Northern England', in H. E. Hallam, ed., The Agrarian History of England and Wales, Volume II: 1042-1350 (Cambridge, 1988), p. 694.

${ }^{36}$ Harvey, Westminster Abbey, p. 224; TNA SC6/871/2 (Stevenage, 1277-8).

37 TNA SC6/871/16 (1293-4); and SC6/984/11 (earl of Devon, 1287-8); SC6/991/20 and SC6/991/25 (Bungay); SC6/964/5 and 9 (Oakham).

${ }^{38}$ Finberg, Tavistock Abbey, p. 78; Bennett, Life on the Manor, pp. 138-9; B. Wells-Furby, The Berkeley Estate 1281-1417, Bristol and Gloucestershire Archaeological Society Monograph (2012), pp. 110, 114.

${ }^{39}$ Hilton, Class Conflict, p. 51. Page, End of villeinage, pp. 18, 37 cites the single example of Woolston (Berks.), where in five years between 1326 and 1348 the sums paid for tallage varied between 13s. 4d. and 60s. 
Contemporary boasts that lords could tallage their villeins 'high and low' were mere rhetoric. ${ }^{40}$ So when manorial documents continued to state that land owed tallage subject to the will of the lord, the purpose of this statement was to reinforce its villein status, not to be taken literally. ${ }^{41}$ As Hyams states, the phrase served as a legal device, not as a reflection of reality, and lawyers in the royal courts were well aware that it was not literally true. ${ }^{42}$ Tallage payments had become codified and ossified during the course of the thirteenth century along with all other elements of the villein's rent package, and lords who tried to change them faced challenge and resistance. ${ }^{43}$

The fourth generalisation is that tallage was neither a universal nor invariable feature of villein tenure, and there are many manors where it did not exist. In Shropshire tallages were 'uneven in incidence and few records of their payment are found after the early fourteenth century'. ${ }^{44}$ Not all manors on the estates of Tavistock abbey and the earldom of Chester rendered tallage. ${ }^{45}$ An extent for Whitnash (Warwickshire) noted explicitly that its servile tenants 'do not give aid' ${ }^{46}$ It is not recorded on the manors of the earls of Clare in south-east England, or on the Surrey manors of Merton College, or on the manors of Harleston (Northamptonshire) and Spalding (Lincolnshire). ${ }^{47}$ Practice was inconsistent even within the same estate, in that some manors held by the same landlord paid tallage while others did not. On the estate of the bishop of Winchester, a group of manors around Winchester did not pay annual tallage whereas a group around Taunton did so. ${ }^{48}$ In 1296-7 exactly one half of the 22 non-Cornish manors of the Duchy of Cornwall (for which accounts have survived) rendered tallage while the other half did not. ${ }^{49}$ Annual fixed tallage was a common feature of the East Anglian manors of the earls of Norfolk, although it was never paid on the earls'

\footnotetext{
${ }^{40}$ B. M. S. Campbell, 'The Agrarian Problem in the Early Fourteenth Century', Past and Present, clxxxviii (2005), p. 42; C. Dyer, Making a Living in the Middle Ages: the People of Britain 850-1520 (London, 2002), p. 142. A note that the villeins of Southam (Warks.) in 1411 owed aid worth 113s. 4d. 'more or less at the will of the lord' was mere legal rhetoric, P. Coss and J.C. Lancaster Lewis, eds., Coventry Priory Register, Dugdale Society, xlvi (2013), p. 585.

${ }^{41}$ M. Bailey, 'The Transformation of Customary Tenures in Southern England c.1300 to c.1550', Agricultural History Review, Ixii (2014), p. 219.

42 Hyams, King, Lords and Peasants, p. 191.

43 J. Hatcher, 'English Serfdom and Villeinage: Towards a Re-Assessment', Past and Present, xc (1981), pp. 1426; S. H. Rigby, English Society in the Late Middle Ages. Class, Status and Gender (Basingstoke, 1995) pp. 10710; Campbell, 'Agrarian Problem', p. 40.

${ }^{44}$ A. J. Kettle, '1300-1540', in G. C. Baugh, ed., The Victoria County History of Shropshire, volume IV: Agriculture (Oxford, 1989), p. 113.

${ }^{45}$ Finberg, Tavistock abbey, p. 78; P. H. W. Booth, The Financial Administration of the Lordship and County of Chester 1272-1377 (Manchester, 1981), p. 142.

46 John, Warwickshire, p. 86.

${ }^{47}$ Neilson, 'Customary Rents', p. 94 for St Paul's. For the Clare manors, see G. A. Holmes, The Estates of the Higher Nobility in the Fourteenth Century (Cambridge, 1957), pp. 150-5, and also TNA SC6/868/16 to 23 and SC6/869/1 to 10 (Standon manor). For the Surrey manors, see H. M. Briggs, ed., Surrey Manorial Accounts, Surrey Record Society, xv (1935); D. Willis, ed., The Estate Book of Henry de Bray c.1289-1340, Camden Society, 3rd Series, xxvii (1916), pp. xiv-xv, 48-54; N. Neilson, ed. A Terrier of Fleet, Lincolnshire (British Academy Records of the Social and Economic History of England and Wales, iv (1920), p. Ixxvii.

${ }^{48}$ A. E. Levett and A. Ballard, The Black Death on the See of Winchester, Oxford Studies in Social and Legal History, V, (Oxford, 1916), pp. 162-77.

49 The eleven manors which not render tallage were Prince's Risborough (Buckinghamshire), Berkhamsted (Hertfordshire), Sundon (Beds.), Newport (Essex), Wilton (Wiltshire), Fordington (Dorset), Henley (Oxfordshire), Benson (Oxfordshire), Osney (Oxfordshire), Bacton (Norfolk) and Howden (Yorkshire): L. M. Midgley, ed., Ministers' Accounts, Volume I, pp. 1-3, 6-7, 12-17, 48-9, 74-82, 91-4, 95-8, 142-8; and L.M. Midgley, ed., Ministers' Accounts of the Earldom of Cornwall 1296-1297, Volume II, Camden Society, $3^{\text {rd }}$ series, Ixviii (1945), pp. 151-2, 202-8. For the eleven manors which did pay tallage that year, see table 3.
} 
large manors of Kelsale and Staverton (Suffolk). ${ }^{50}$ On the eight manors on the Isle of Wight held by the earl of Devon in 1317-18 and 1331-2, two manors did not render tallage. ${ }^{51}$

The examples above indicate that anything from 25\% (earls of Devon) to 50\% (Duchy of Cornwall) of manors on the same estate did not render servile tallage, presumably because it had not been customary on those particular manors. The absence of annual tallage was most prominent on manors held by lower status landlords, but this point is hard to prove quantitatively because of the extremely poor survival of manorial documents from such estates. The Hundred Rolls of 1279-80 contain rudimentary manorial extents from a large sample of manors held by a wide range of lords, including many small lay manors, and also record liability for tallage-at-will. The surviving rolls for Warwickshire reveal that the entries for $54 \%$ of manors in Stoneleigh Hundred, and $58 \%$ in Kineton Hundred, do not mention liability for servile tallage. ${ }^{52}$ This might simply reflect clerical inconsistency, but it might indicate the absence of tallage from many smaller manors held by lower status lords. Manorial accounts are the best source to test this point, because they provide the most direct evidence for the collection of-as opposed to the liability for-tallage. A sample of 80 manorial accounts dating between 1300 and 1390 from sixteen small lay manors in Suffolk held by different and unconnected lords reveals just how rare tallage was on such estates, even in the period when its collection should have been most active..$^{53}$ Just one of these 80 accounts contains a reference to the payment (or, indeed, the non-payment) of tallage..$^{54}$ More case studies are clearly needed, but it is already proven that not all manors imposed tallage, especially on small manors held by lesser lords.

The fifth generalisation is that even when liability for tallage was established, and even when villeins on a particular manor paid it as a regular sum, in some years it was not charged. Landlords could, and did, forego their theoretical and customary right to levy tallage. Between 1278 and 1304 the villeins of Hollesley paid tallage every year for which accounts have survived, but then nothing in either 1305-6 or 1308-9 (see table 2). The customary tenants of Sevenhampton (Wiltshire) paid an annual tallage to Isabel de Forz, Countess of Aumale, every year between 1269 and 1276, when the sums varied between 60s. and 80s. ${ }^{55}$ However, nothing was paid in September 1277, when it was

\footnotetext{
${ }^{50}$ For Kelsale, see SRO B[ury St Edmunds] HD1538/279/1 and 2; for Staverton, see Bailey, Decline of Serfdom, p. 223.

${ }^{51}$ The two were Brigherne and Thornhey. Compare the information presented in Table 2, with TNA SC6/985/9, mm. 8-9, and SC6/985/15, m. 3.

52 John, Warwickshire.

53 In order to qualify for the sample, at least one complete account roll had to be extant from the period 1300 1390 from a manor which was either small (>500 acres) or held by a lesser lord. The manors are: Akenham, 1384-5, 1387-8, SROI HD1469/7 and 8; Boulge, 1356-7, 1372-3, SROI HD1538/139/ 1 and 2; Cretingham, 13745, SROI HA10/50/18/4.4 (8); Gipping, 1318-9, 1328-9, 1336, 1347, SROI HD1538/236/15 to 20; Glemham, 1355-6, SROI 1538/238/1; Harkstead, 1341-2, SROI S1/10/6.6; Holton, 1375-6; SROI HA246/A4/7; Horham, 1328-9, 1352-3, 1363-4, 1370-1, 1371-2, SROI HA68/484/318; Icklingham, 1329-30, 1330-1, 1331-2, 1332-3, 1333-4, 1134-5, 1335-6, 1337-8, 1339-40, 1340-1, 1342-3, 1343-4, 1345-6, British Library, Add. Rolls 13190 to 13200; Kingston, C[ambridge] U[niversity] L[ibrary], EDC 7/14/C/2 to 36; Loudham Brerdesilde, 1328-9, SROI HD1538/295/1; Loudham, 1352-3, 1372-3, 1380-1, 1383-4, 1384-5, SROI HD1538/295/2 to 6; Tattingstone, 1369-70, 1377-8, 1378-9, 1387-8, SROI HB8/1/817 to 820; Thelnetham, 1375-6, 1381-2, SROI HD1538/380/7 and 8; Walsham High Hall, 1327-8, 1373-4, SROB, HA504/3/1b, HA504/3/1c; Whepstead, 1332-3, SROI HD1538/219.

${ }^{54}$ Recognition was included in the income from courts in 1333-4 at Kingston, CUL EDC 7/14/C/13. The annual court income from these manors was low, usually around six shillings, so it is highly unlikely that other recognition or tallage payments were hidden within court revenues.

${ }^{55}$ Farr, Accounts and Surveys, pp. 31, 39, 50, 60, 71.
} 
'pardoned by the lord', nor in any of the subsequent ten years: the sources then cease, so we cannot know what happened thereafter. ${ }^{56}$ The last recorded payment of tallage in 1275-76 coincides with the last full year of Isabel de Forz's ownership of the manor, and it appears that the new lord-Adam de Stratton-decided not to collect it after his acquisition of the manor in November $1276 .{ }^{57}$ In none of these cases are the reasons for foregoing tallage given. ${ }^{58}$

These five general characteristics of tallage around c.1300 are usefully illustrated by the 24 manors on the estate of Ogbourne priory, which were scattered from Norfolk to Wiltshire (see table 3). In the seven years for which records survive between 1247 and 1289 no arbitrary tallages were levied, and the majority of manors rendered an annual tallage, usually rounded to the nearest pound or (half) mark. A handful of manors paid the same sum each year (Hungerford, Swyncombe and Weedon Bec), although most paid a slightly different sum each year. Only one manor on the estate, (Dunton) did not pay any tallage, and a further eight manors did not pay tallage in every one of the six years. For example, villeins on the manor of Hooe paid $f 2$ tallage in $1272-3$, but nothing at all in subsequent years, while those at Blakenham paid 6s. 8d. in 1276-7, and again in 1281-2, but nothing in $1272-3,1283-4,1288-9$, or $1297-1300 .{ }^{59}$ Reasons are not given. The manors also owed recognition upon the accession of a new abbot of the mother house, Bec, which in 1281-2 was paid to the King as temporary holder of the estate during a vacancy at Bec. In that year villeins on most manors paid recognition in addition to tallage. ${ }^{60}$ In most cases, the level of payment was equal to, or slightly lower than, the regular tallage payment. Even Dunton, which did not render annual tallage, paid 13s. 4d. recognition.

TABLE 3 ABOUT HERE

2

How was the level of tallage determined and who paid? By c.1300 four principal methods are evident. One method was to fix a set rate upon each villein as head of household, usually linked to the size of the villein's landholding. ${ }^{61}$ In 1233 the lord of a Norfolk manor agreed to fix annual tallage at $12 \mathrm{~d}$. on every villein, and in 1279 unfree tenants of a Warwickshire manor each owed 2s. ${ }^{62}$ Villeins at Wistow (Hunts.) paid at fixed rates of $10 \mathrm{~d}$. per virgate, and $1 \frac{1}{2} \mathrm{~d}$. per cotland. ${ }^{63}$ Similarly, tallage was fixed at the rate of $40 \mathrm{~d}$. per bovate on the main Lenton priory manors of Radford, Kyketon and Lenton (Nottinghamshire) , and cottagers paid a maximum rate of $6 \mathrm{~d}$., or less according

\footnotetext{
${ }^{56}$ Farr, Accounts and Surveys, pp. 81, 91, 100, 109, 118, 127, 135, 143, 152, 161, 170, 178; Pugh, Court Rolls, pp. 13, 33, 39-41.

${ }^{57}$ Pugh, Court Rolls, pp. 1-2.

${ }^{58}$ The Duchy of Lancaster sometimes chose not to levy tallage where it was due, E. C. Lodge and R. Somerville, eds., John of Gaunt's Register 1379-1383, volume II, Camden Society, 3rd Series, Ixviii (1945), p. xxi.

${ }^{59}$ See table 1, and M. C. Chibnall, ed., Select Documents of the English Lands of the Abbey of Bec, Camden Society, 3rd Series, Ixxiii (1951), pp. 172, 176, 182.

${ }^{60}$ Chibnall, Compotus Rolls, pp. 86, 95

${ }^{61}$ Neilson, 'Customary Rents', pp. 90-1; E. B. Fryde, 'The Tenants of the Bishops of Coventry and Lichfield, and of Worcester, after the Plague of 1348-9', in R. F. Hunnisett and J. B. Post, eds., Medieval Legal Records edited in Memory of C.A.F. Meekings (London, 1978), p. 234, 236.

62 E. Miller and J. Hatcher, Medieval England: Rural Society and Economic Change, 1086-1348 (London, 1978), p, 130; Hilton, Class Conflict, p. 51. See also Wells-Furby, Berkeley Estate, p. 114.

${ }^{63}$ N. Neilson, Economic Conditions on the Manors of Ramsey Abbey (Philadelphia, 1898), p. 71.
} 
to their ability. ${ }^{64}$ The contribution of each customary tenant to the fixed recognition payment of 10 marks at Salton (Northumberland) was calculated 'each in proportion to his holding', recognition at Norton (Hertfordshire) was assessed 'in proportion to [the villein's] goods', and at Barwell

(Leicestershire) it was paid at 4s. per virgate. ${ }^{65}$ This method explains why the sums rendered as tallage each year remained broadly consistent, because the number and occupation rate of liable landholdings hardly changed. It also, importantly, establishes the principle of capping the liability for tallage.

A second method was to assess tallage on the basis of the number of livestock held by each villein, which thus involved a fresh assessment on each occasion tallage was due. ${ }^{66}$ This comprised the main method of assessment on the estates of the earls of Norfolk and Ramsey abbey. ${ }^{67}$ Gloucester abbey could amerce its villeins at will if they tried to conceal livestock at the time of tallage. At Aldsworth (Gloucestershire) unfree tenants paid tallage at the rate of $2 \mathrm{~d}$. per horse and ox, and $1 / 4 \mathrm{~d}$. for every sheep and pig, and those at Northleach and Eastleach (Gloucestershire) paid 'according to the quantity of their land and number of animals'. ${ }^{68}$ During the thirteenth century recognition was re-assessed upon the election of each abbot of Bury St Edmunds based upon villein ownership of livestock on each manor. Detailed listings from two manors in 1302 provide exceptional insights into the mechanics of assessment. At Coney Weston (Suffolk) the 77 paying 'customars' included 14 women, only one of whom was described as a widow. The 20 'customars' at Culford (Suffolk) included one woman, and also two men excused on the grounds of poverty. Liability extended to freemen who held villein land and to landless serfs: those who had no livestock were either exonerated or charged $6 \mathrm{~d}$. Contributions here were not charged at a fixed rate per head of beast, but assessments were made in multiples of $6 \mathrm{~d}$. to a maximum payment of $6 \mathrm{~s}$. $8 \mathrm{~d}$., based broadly upon the number of livestock owned. ${ }^{69}$

A third method, and much the simplest and easiest for the lord to administer, was to specify a rounded sum each year for the manorial community to raise among themselves. The collective responsibility is occasionally stated explicitly. In 1291, for example, the bondmen of Walcote (Leicestershire) owed 100s. 'jointly' (communiter) and in 1366 John Vincent of Stoke Abbott (Dorset) was required to contribute 'with his neighbours' to a communal aid of 40 s. each year. ${ }^{70}$ It is not clear whether a communal sum was the original format, or whether it had been introduced latterly to replace the inconvenience of annual reassessments. Tallage at North and East Leach (Gloucestershire) had been originally based upon annual reassessments of villein land and livestock,

\footnotetext{
${ }^{64}$ F. B. Stitt, ed., Lenton Priory Estate Accounts 1296 to 1298, Thoroton Society, xix (1959), pp. 19-20. For other examples, see Finberg, Tavistock abbey, p. 78; and Neilson, A Terrier of Fleet, p. 13.

${ }^{65}$ Britnell, Black Book of Hexham, p. 140. P. Foden, ed., Records of the Manor of Norton in the Liberty of St Albans 1244-1539, Hertfordshire Record Society, xxix (2015), p. 112; TNA DL43/14/3, f. 70. A villein at Priors Marston (Warks.) paid tallage pro quantitate terre sue, John, ed., Warwickshire, p. 207.

${ }^{66}$ Vinogradoff, Villeinage, p. 293; Neilson, 'Customary Rents', p. 91.

${ }^{67}$ F. G. Davenport, The Economic Development of a Norfolk Manor (Cambridge, 1906), p. 46; villeins of Ramsey abbey paid two tallages each year, one of which was a charge for the right to pasture animals at the rate of $1 / 2 \mathrm{~d}$. for each great beast and 1d. for every eight pigs and eight sheep, Neilson, Economic Conditions, p. 71.

${ }^{68}$ Secundum quantitatem terrae et numerum animalium: Hart, History and Cartulary, pp. 182, 191. See also Stitt, Lenton Priory, p. 20.

${ }^{69}$ B[ritish] L[ibrary], Harl. Ms. 230, f. 62; E. Powell, A Suffolk Hundred in 1283 (Cambridge, 1910), appendix 7.

${ }^{70}$ Bondi qui dant tallagium pro voluntate domini quod valet communiter Cs.: Raban, White Book, p. 91. At Stoke Abbott, idem dabit de auxilio ad festum sancti Michaelis cum vicinis suis communiter xls.' , for which see H. E. Salter, ed., The Cartulary of the Abbey of Eynsham, volume II, Oxford Historical Society, li (1908), p. 129.
} 
but by 1266-7 a rounded and collective sum was used instead. ${ }^{71}$ After 1335 on the estate of Bury St Edmunds abbey a fixed communal sum replaced individual and fresh re-assessments based on villein livestock: for example, in 1279 and 1302 individual re-assessments of recognition at Fornham All Saints (Suffolk) generated 49s. 9d. and 32s. 3d. respectively, but, from the election of abbot William Barnham in 1335, recognition became fixed at $45 \mathrm{~s}$. thereafter..$^{72}$ Recognition here was levied on hereditary serfs and villein landholders. This was also a feature at Wimbotsham (Norfolk). ${ }^{73}$

Extant sources seldom reveal how a communal charge was apportioned, although F.M. Page assumed that it fell 'with a rough equity on all villein landholders' ${ }^{74} \mathrm{~A}$ few manor courts record the appointment of 'assessors' of tallage from among the leading villein tenants for the purpose of apportioning communal payments, who must have applied some local guidelines for allocating the contributions. ${ }^{75}$ The court of Blakenham (Suffolk) fined two villeins $12 \mathrm{~d}$. each for refusing to pay their contribution to a collective tallage as determined by their neighbours. ${ }^{76}$ Very occasionally the exact division of a lump sum between villeins is recorded as, for example, in 1277 when a recognition charge of 56s. was split among 32 villeins of Norton (Hertfordshire): the lowest rated villein paid $6 \mathrm{~d}$., the highest $6 \mathrm{~s}$., and all assessments were in multiples of $6 \mathrm{~d} .{ }^{77}$ Established mechanisms for allocating fixed-sum tallages were probably adopted to apportion payment among individuals of the Crown's fixed Lay Subsidy when it became a fixed charge upon communities after 1334. It is significant that peasants seeking to raise funds among themselves for other purposes are often described as collecting 'tallages'. ${ }^{78}$ Thus the ways in which villeins determined their contributions were more varied than Page assumed, and the liability of any one individual was capped. ${ }^{79}$

The fourth, and final, method, of determining the level of tallage was the rarest, as well as the most remarkable: the sum was determined by the community of villeins. This custom is clearly and unequivocally stated at Walsham-le-Willows (Suffolk), where the sums rendered for recognition varied from $6 \mathrm{~s} .8 \mathrm{~d}$. in 1316, 13s. $4 \mathrm{~d}$. in 1325 , to $f 5$ in 1331. In 1361 40s. was paid, with the explanation that the payment was neither a fixed amount nor at the lord's will, 'but only as much as at the courtesy of the homage' ${ }^{80}$ A variation on this practice is recorded at Cratfield (Suffolk), where in 1292 the villeins paid their standard annual tallage of 53s. 2d., but also contributed an additional,

\footnotetext{
${ }^{71}$ Thus at Northleach $\mathrm{f6}$ 13s. 4d. was owed in communi: Hart, History and Cartulary, p. 182.

${ }^{72}$ F. Hervey, ed., Pinchbeck Register of the Abbey of Bury St Edmunds and Related Documents, Volume I (Brighton, 1925), p. 470 (1279); BL Harl. Ms. 230, f. 62 (1302); SROB E3/15.7/1.1 (1335); and 45s. were still being demanded in the 1380s, SROB E3/15.6/1.18. The decision to move to a communal sum in 1335 may have been triggered by the introduction in 1334 of fixed communal sums on individual vills for royal taxation.

${ }^{73}$ NRO, Hare 4238, court held February 1353.

74 Page, Crowland Abbey, p. 106.

${ }^{75}$ Bailey, Decline of Serfdom, p. 183.

${ }^{76}$ F. W. Maitland, ed., Select Pleas in Manorial and Other Seigniorial Courts, volume I (Selden Society, 1889), p. 12.

${ }^{77}$ Foden, Norton, p. 22.

78 In 1385 customary tenants and villeins of Thurston (Suffolk) collected tallagium among themselves to create a legal fighting fund, E. Powell, The Rising in East Anglian in 1381 (Cambridge, 1896), p. 65. In 1318 local people attacked the manors of St Augustine's abbey on Thanet (Kent), who were described as having 'made collections and assessed divers tallages among themselves' in a manner mirroring the employment of custom: A. H. Davis, ed., William Thorne's Chronicle of St Augustine's Abbey Canterbury (Oxford, 1934), pp. 432-3. I am grateful to Chris Briggs for this reference.

${ }^{79}$ Harvey, Westminster Abbey, p. 224.

${ }^{80}$ Bailey, Decline of Serfdom, p. 107.
} 
one-off, payment of 20s. 'at the will of the nativi' ${ }^{81}$ Similarly, in 1300 the bondmen of Forncett (Norfolk) gave an additional 20s. as a gift. ${ }^{82}$ The reasons are not given. The agency of villeins in determining the level of tallage, or in making additional voluntary contributions, is remarkable, given that servile tallage was supposed to be determined at the will of the lord. It might just be another example of the action of local custom in shaping and ossifying its local operation. However, it might have been a canny legal tactic: after all, a person who could demonstrate that aid was given consensually, rather than by arbitrary imposition, had a legal pretext for arguing they were free not servile. $^{83}$

How burdensome was tallage as a fixed and annual levy, especially around 1300 when general levels of peasant welfare were low? Did it add materially to their difficulties in making ends meet? As we have seen, most historians have assumed (but not proved) that it was highly onerous. ${ }^{84}$ Martin's strident statement that 'villeins often paid an amount almost equivalent to the rent paid for holdings' is simply an unsubstantiated guess..$^{85}$ In contrast, Kanzaka's quantitative analysis of the Hundred Rolls of 1279-80 concluded that rents on villein holdings were still lower than the market level even when the cost of tallage was added. ${ }^{86}$ Dyer argues that it constituted a permanent increment to the burden of villein rent, which was possibly onerous and would probably cause hardship in years of distress. ${ }^{87}$ Likewise, Bennett warned that even a fixed and predictable tallage was not necessarily bearable, because its 'inelasticity made no allowance for bad seasons or altering conditions in the neighbourhood'.$^{88}$

The most direct and informative way of establishing the burden that annual tallage placed upon villeins is to express the sum as a percentage of the annual rent charge of their holdings, but unfortunately the amount of tallage due from each individual holding is seldom recorded. There are a handful of rare exceptions. Annual tallage was fixed at 4s. per annum per yardland at Bishop's Cleeve (Gloucestershire), and therefore added an $18 \%$ supplement to the basic cash rent of 22s., and fixed annual tallage added around $30 \%$ to the rent of a standard villein holding on the Lancastrian estates in Staffordshire. ${ }^{89}$ In 1291 annual tallage increased the annual level of cash rent by $48 \%$ on 10-acre villein holdings at Torpel (Northamptonshire), by 59\% on virgates at Upton (Northamptonshire) and $50 \%$ at Ham (Gloucestershire)..$^{90}$

In the absence of this type of detailed and precise information for the vast majority of manors, the extent to which tallage added to the annual villein rent charge can be estimated roughly by expressing the annual tallage payment as a percentage of the fixed assize rents on an individual manor. This is a crude measure, but carries the major benefit that it can be readily calculated from the basic information contained within most manorial accounts. The method for making such

\footnotetext{
81 TNA SC6/995/6.

82 Davenport, Economic Development, p. 46.

${ }^{83}$ Hyams, King, Lords and Peasants, p. 193.

${ }^{84}$ Neilson, 'Customary Rents', p. 90.

85 The statement is not supported by any evidence or footnote, Martin, Transition, p. 42.

${ }^{86} \mathrm{~J}$. Kanzaka, 'Villein Rents in Thirteenth-Century England: an Analysis of the Hundred Rolls of 1279-80', Economic History Review, $2^{\text {nd }}$ Series, Iv (2002), p. 613.

87 Dyer, 'Ineffectiveness of Lordship', pp. 73-4.

${ }^{88}$ Bennett, Life on the Manor, p. 140.

${ }^{89}$ C. Dyer, Standards of Living in Later Medieval England: Social Change 1200-1540 (Cambridge, 1989), p. 115; Hilton, English Peasantry, p. 237.

${ }^{90}$ Raban, White Book, pp. 37-8 and 41-2: eleven villeins at Torpel paid 2s. 6d. annual rent, and collectively paid 13s. $4 \mathrm{~d}$. in tallage each year, while six virgaters paid 7s. $6 \mathrm{~d}$. rent each and $26 \mathrm{~s}$. $8 \mathrm{~d}$. tallage collectively. WellsFurby, Berkeley Estate, p. 91.
} 
calculations is clearly laid out in tables 4 and 5, which provide information from a sample of 24 manors (for which accounts survive and where tallage was paid) on three aristocratic estates.

\section{TABLES 4 AND 5 about here}

These figures must be treated with some caution. First, they express tallage as a percentage of the money component of the rent package on customary holdings, but cash payments comprised just part of the overall package, which also contained sizeable non-cash elements, such as rents in kind, labour services and other servile incidents. Second, the significance of the figures depends upon whether the basic cash rents upon which they are based reflected the market value of land or were pinned by custom at artificially low levels: for example, tallage charged at $50 \%$ of a commercial rent would be much more onerous than $50 \%$ of an ossified customary rent set far below the prevailing market level. Most historians now accept that by c.1300 villein cash rents were stuck far below commercial rates, but we cannot know exactly how far for any given manor. ${ }^{91}$ Notwithstanding these caveats, three features are readily apparent: the amount rendered as tallage was usually less than the annual rent charge; there was no consistency in the extent to which annual tallage added to the rent burden of customary holdings within the same estate; and changes in the level of tallage on the same manor (Cratfield, Forncett) in this period increased the rent burden upon villeins.

What of the burden imposed on those manors where only occasional recognition, and not annual tallage, was charged? The manors of Chevington and Hargrave (Suffolk) paid recognition upon the election of the abbot of Bury St Edmunds in 1279, 1302, 1312 and 1335, but no annual tallage. The sums paid for recognition were variable before 1335 . In these years recognition mainly comprised between one third and one half of the annual rent charge, with the exception of a high levy at Hargrave in 1302 (table 6), proportions which are broadly consistent with those charged for annual tallage. These specific examples reinforce the general observation that lords did not obtain huge, one-off, windfalls through recognition. If we express the total payments from all recognition between 1300 and 1349 as a percentage of the total of all annual rent paid during the same period, recognition represented at most $3 \%$ of customary rents at Chevington and $5 \%$ at Hargrave. ${ }^{92}$

\section{TABLE 6 about here}

The variety in the weight of tallage from one manor to another is readily apparent from Tables 4 to 6 , but how does this aggregate to the level of the estate? Barbara Harvey once calculated that it comprised less than $10 \%$ of the level of rents on the conventual manors of Westminster abbey. ${ }^{93} \mathrm{~A}$ simple calculation reveals that in 1297-8 annual tallage charged across the estate of Lenton priory (Nottinghamshire) amounted to $74 \%$ of its fixed rents, and on the estate of Worcester Cathedral Priory it amounted to $52 \%$ in $1291-2,56 \%$ in $1293-4$ and 51\% in $1294-5 .{ }^{94}$ Table 7 aggregates the

\footnotetext{
${ }^{91}$ Hatcher, 'English Serfdom', pp. 14-21; Rigby, English Society, p. 56; Kanzaka, 'Villein Rents', pp. 608-18; S. Raban, A Second Domesday? The Hundred Rolls of 1279-80 (Oxford, 2004), pp. 132-8; Campbell, 'Agrarian Problem', pp. 40-5; P.R. Schofield, Peasant and Community in Medieval England (Basingstoke, 2003), p. 30.

92 The sums and sources are contained in table 6 . For the purpose of this calculation I have assumed that the sums paid in 1279 (60s. at Chevington, and 49s. 6d. at Hargrave) were also paid in both 1302 and 1312, because on both these dates the sums rendered have not survived.

93 Harvey, Westminster Abbey, p. 224

94 Tallage on the Lenton estate amounted to $£ 135 \mathrm{~s}$. $2 \mathrm{~d}$., and fixed rents, excluding commutations, amounted to $f 18$ 0s. 4d, Stitt, Lenton Priory, pp. 17-20. On the Worcester estate, $£ 5216 \mathrm{~s}$. $9 \mathrm{~d}$. rents and $£ 27 \mathrm{ss} .5 \mathrm{~d}$. tallage (1291-2), £49 6s. 6d. and $£ 27$ 1s. 4d. (1293-4), and $£ 53$ 13s. 1d. and $£ 27$ 6s. 6d. (1294-5), J. M. Wilson
} 
figures from tables 3,4 and 5, and provides additional information from three other estates. These figures do not include income from recognition, and they do not include manors where tallage was not levied, so they are merely indicative of the weight of tallage on some of manors within these seven estates where tallage was levied.

\section{TABLE 7 about here}

The figures are reasonably consistent, despite the limitations of this simple methodology. They indicate that tallage typically amounted to between one quarter and one half of the level of fixed rents on major aristocratic and ecclesiastical estates, nothing like the equivalent of a year's cash rents proposed by Martin..$^{95}$ Even these proportions tend to overstate the actual impact of tallage upon the villein's total resources, because cash rents were only part of the total rent package and in c.1300 were usually far below the real value of land. Only when annual tallage was occasionally supplemented by a recognition payment was the combined charge a weighty burden upon villeins. The weight upon a single manor varies from c. $9 \%$ to c. $220 \%$ within one estate, and from $1 \%$ to $220 \%$ across the whole sample, which illustrates the unevenness with which the burden of villeinage fell upon villeins. ${ }^{96}$

3

While tallage-at-will did not vary markedly or arbitrarily from year to year, it was prone to some variation over time. Where the payment was linked to the number of villein livestock, then the total amount raised was likely to fluctuate slightly from year to year even while the rate remained fixed. There is also evidence that the level of some 'fixed' communal payments were also changed occasionally. ${ }^{97}$ For example, levels of tallage were increased in 1278-9 on some of the East Anglian manors of the earls of Norfolk: in that accounting year the annual charge upon the villeins of Forncett (Norfolk) rose from $f 613 \mathrm{~s}$. $4 \mathrm{~d}$. to $£ 9$ 13s. $4 \mathrm{~d}$., and from $£ 4$ to $£ 413 \mathrm{~s}$. 3d. at Hollesley (Suffolk), sums which then continued to be levied subsequently. ${ }^{98}$ Similarly, between the 1270 s and 1300 s Crowland abbey received fixed annual payments from its three manors in south Cambridgeshire, but then in the 1310 s raised the level annually payable from each. ${ }^{99}$ The reasons for these increases are not stated, although they were clearly the consequence of an estate-wide policy, and we cannot know if they were negotiated, imposed or resented. The absence of arrears or respites for these payments in the same accounts indicates that they were paid. They may have reflected the earl's need for cash in the late 1270s, or the abbey's response to rapid inflation in the early 1300s. On the Cornish manors of the Duchy of Cornwall after 1333, tallage became a regularly renegotiated sum whose purpose was to obtain a proper commercial rent from customary landholdings whose annual rental charge had long been fixed at an artificially low level. The amount

and C. Gordon, Early compotus rolls of the Priory of Worcester, Worcestershire Historical Society (1908), pp. 8, 15, 24.

95 Martin, Transition, p. 42.

${ }^{96}$ M. Bailey, 'Villeinage in England: a Regional Case Study c.1250-1349', Economic History Review, $2^{\text {nd }}$ Series, Ixii (2009), pp. 430-57.

97 Bennett, Life on the Manor, pp. 139-40.

98 Davenport, Development of a Norfolk Manor, pp. 37-43; TNA SC6/998/19 to 29 (Hollesley). I am grateful to Val Dudley for supplying the Hollesley figures.

99 Page, Crowland Abbey, pp. 309-12. 
payable was fixed for each manor and payable in equal instalments for the next seven years, at which point the amount was renegotiated for the next seven years, and so on. ${ }^{100}$ The Cornish example is exceptional, perhaps unique, though it hints at an underlying link between the level of tallage and the commercial value of land.

These variations are indicative of some elasticity in the charges for tallage. At Ham (Gloucestershire) the absolute payments of tallage fell over the course of the fourteenth century, although it remained steady at c. $22 \%$ of the monetary value of customary rents: the proportion fell to a low point of $16 \%$ during the famine year of $1316-17$ (Table 8). ${ }^{101}$ The reduction during the great famine was not commensurate with the distress suffered by the peasantry, but it does indicate that tallage charges were not as inelastic in moments of crisis as Bennett feared. ${ }^{102}$ Recognition charges on the manors held by the abbot of St Edmund were lower in the 1330s than they had been around c.1300: in 1279, when recognition was a variable charge, it comprised $62 \%$ of the annual cash value of assize rents at Chevington and $92 \%$ of those at Hargrave, but when the charge became fixed in 1335 the burden fell to $42 \%$ and $59 \%$ respectively (table 6 ). The fall almost certainly reflects an adjustment to prevailing economic conditions, following the loss of livestock and sheep to successive murrains in the 1310s and 1320s, and the impact of monetary deflation in the 1330s.

\section{TABLE 8 ABOUT HERE}

The example of Ham also exemplifies the tendency of tallage payments to fall following the Black Death of 1348-9. Annual tallage paid at Woolston (Berkshire) fell from a mean of 31s. $5 \mathrm{~d}$. between 1326 and 1348 (five years) to 17s. 2d. between 1351 and 1382 (eleven years). ${ }^{103}$ The fall could be precipitous, such as the reduction from $f 10$ per annum in the 1320 s to just $f 2$ in the 1380 s at Oakington (Cambridgeshire), and similarly from over $£ 10$ in 1347 at Hurdwick (Devon) to under $£ 2$ in 1387. ${ }^{104}$ The bishopric of Worcester obtained $f 4112 \mathrm{~s} .53 / 4 \mathrm{~d}$. from annual tallage in 1302 , nothing in 1349,1353 and 1361, and just $f 15$ 9s. in 1364, partly due to empty holdings following successive plagues but also due to a reduction in the rate payable from, for example, $2 \mathrm{~s}$. per virgate to $6 \mathrm{~d}$. on its manor of Bredon (Worcs.): similarly, recognition payments on the same estate fell from $\mathrm{f} 40 \mathrm{fs}$. 4d. in 1302, to $f 18 \mathrm{~s} .8 \mathrm{~d}$. in 1349 and $£ 5$ 0s. 8d. in $1364 .{ }^{105}$ Elsewhere, landlords notionally charged villeins for tallage at its pre-Black Death level, but then routinely respited a given sum each year in acknowledgement of the reduced capacity of the tenant base to pay. For example, during the $1380 \mathrm{~s}$ the Duchy of Lancaster relaxed $12 \%$ of the annual tallage due from the Forest of Knaresborough (Yorkshire) each year. ${ }^{106}$ Such reductions are entirely consistent with a reduction in the number of

\footnotetext{
100 J. Hatcher, Rural Economy and Society in the Duchy of Cornwall 1300-1500 (Cambridge, 1970), p. 61.

${ }^{101}$ Wells-Furby, Berkeley Estates, pp. 91, 110, 268, 270.

102 Bennett, Life on the Manor, p. 140.

103 Page, End of Villeinage, pp. 37 and 66: in 1363 nothing was charged.

104 Page, Crowland Abbey, pp. 309-12; Finberg, Tavistock abbey, p. 78; E. Miller, 'Tenant Farming and Tenant Farmers: Yorkshire and Lancashire', in E. Miller, ed., The Agrarian History of England and Wales, Volume III: 1348-1500 (Cambridge, 1991), p. 607.

105 Fryde, 'Tenants of the Bishops', p. 236 and table E.

${ }^{106}$ E.C. Lodge and R. Somerville, eds., John of Gaunt's Register 1379-1383, volume I, Camden Society, $3^{\text {rd }}$ series, Ivi (1937), pp. xix, xxi, and 134, where a reduction of $64 \mathrm{~s}$. $2 \mathrm{~d}$. in the total of $£ 1318 \mathrm{~s} .4 \mathrm{~d}$. tallage due from the Forest of Knaresborough was permitted. See table 3 for the tallage owed at Knaresborough.
} 
landholders on a manor and the declining commercial value of land. ${ }^{107}$ They may also reflect a shift locally from traditional villein tenure to contractual tenures in the second half of the fourteenth century, because leaseholders of customary land did not usually pay tallage. ${ }^{108}$

The decline in the level of tallage payments from the mid-fourteenth century exemplifies the wider decline in servile incidents as part of the general dissolution of villeinage. The orthodox view is that landlords stoutly defended villeinage in the immediate aftermath of the Black Death, but then a combination of mounting peasant resistance and the violence in the Peasants' Revolt of 1381 warned them off such coercive policies and resulted in its abandonment between c.1380 and c. $1420 .{ }^{109}$ A recent study, however, has proposed an earlier chronology of c.1350 to c.1390, by arguing that landlords were replacing the old villein tenures with more attractive (and less stigmatic) cash tenures in their scramble for tenures in the wake of the Black Death of 1348-9. ${ }^{110}$

Reconstructing a clear chronology of the decline of tallage from the published case studies of various manors and estates is impossible, because the relevant information is not presented in a systematic fashion, but there is plenty of evidence from primary sources to support the view that tallage disappeared quickly from many manors in the second half of the fourteenth century. In the 1350 s it was dropped from the estate of the Bishopric of Coventry and Lichfield, and from nine manors in East Anglia and Oxfordshire. ${ }^{111}$ In the early fourteenth century annual tallage had been prominent on the East Anglian manors of the earl of Norfolk (Table 2), but it is not recorded in the first set of manorial accounts to survive from across the estate after the Black Death (dating from the 1390s). ${ }^{112}$ Tallage evidently disappeared here soon after the Black Death, as part of a wider move to retain and attract tenants to customary land by removing the old stigmatic elements of villeinage. ${ }^{113}$ Recognition was last levied in 1350 on two Hertfordshire manors held by the cellarer of St Alban's abbey, and in 1373 at Walsham-le-Willows (Suffolk). ${ }^{114}$ In 1279 recognition payments totalling $f 80$ 7s. 11d. had been generated from the estate of the cellarer of Bury St Edmund's abbey, but there is no record of its payment after 1349 on the cellarer's manors of Fornham St Martin and Great Barton (Suffolk), although in the 1380 s an unsuccessful attempt was made to collect it. ${ }^{115}$ Likewise, recognition was not requested on the cellarer's main manor of Mildenhall (Suffolk) in 1390 upon the election of William de Cratfield, or again in 1429 upon the election of William Curteys. ${ }^{116}$

\footnotetext{
${ }^{107}$ Indeed, Fryde attributes the collapse of recognition in the 1350s on the bishopric of Worcester estates in Warwickshire and Worcestershire directly and solely to the reduction in the number of customary tenants, Fryde, Peasants and Lords, p. 61.

${ }^{108}$ Bailey, 'Transformation', pp. 189-203.

${ }^{109}$ This standard interpretation is effectively summarized in G. L. Harriss, Shaping the Nation. England 13601461 (Oxford, 2005), pp. 226-42.

${ }^{110}$ Bailey, Decline of Serfdom, pp. 287-301; M. Bailey, 'The Myth of the Seigniorial Reaction in England after the Black Death', in M. Kowaleski, J. Langdon and P. R. Schofield, eds., Peasants and Lords in the Medieval Economy. Essays in honour of B.M.S. Campbell (Turnhout, 2016), pp. 147-72.

${ }^{111}$ Fryde, Peasants and Landlords, pp. 62-3; Bailey, Decline of Serfdom, pp. 107-8, 115-16, 163, 262-3, 288.

112 Dunningworth, TNA SC6/995/25 (1390-1); Ditchingham, TNA SC6/934/10 (1397-8); Framingham, TNA SC6/935/38 (1399); Kelsale, TNA SC6/1001/1 (1398-9); Earl Soham TNA SC6/1004/16 (1397-8); Earl Stonham SROB HD1538/364.

${ }^{113}$ Davenport, Economic Development, pp. 46 and 54; Bailey, Decline of Serfdom, pp. 199-202, 232-3.

${ }^{114}$ Foden, Norton, p. 147; and D. Noy, ed., Winslow Manor Court Books, Part I 1327-1377, Buckinghamshire Record Society, xxxv (2010), p. 256, and D. Noy, ed., Winslow manor court books, Part II 1423-1460,

Buckinghamshire Record Society, xxxvi (2011); Bailey, Decline of Serfdom, p. 107.

115 Pinchbeck Register, pp. 467-9; Bailey, Decline of Serfdom, p. 263.

${ }^{116}$ There is no mention of recognition in the relevant manorial account of $1390-1$ nor in the relevant court rolls of 1429-30, SROB E18/455/1 and E18/451/4.
} 
The survival of tallage into the fifteenth century was unusual. After 1400 it is recorded on just three manors out of a sample of 38 spread across East Anglia and the southern Midlands. ${ }^{117}$ It survived mainly on major ecclesiastical estates, such as Crowland and Westminster abbeys, and great aristocratic estates, though even here the quantum fell. ${ }^{118}$ In 1479-80 tallage was still charged on three of the eight Warwickshire manors of the Duke of Clarence, although it was only a sizeable levy on one of them. ${ }^{119}$ The Honour of Richmond was levying sizeable tallages on many of its manors in mid-century, and the earls of Northumberland were still notionally levying recognition in the early sixteenth century. ${ }^{120}$

The estate of the Duchy of Cornwall provides a rare example of the survival of tallage throughout the fifteenth century and beyond, although this was largely due to its peculiar format as a regularly renegotiated assession fine. Since 1333 tallage had been fixed on each manor for a seven year period, and then re-set for the next seven-year period. It therefore served as a regular assession fine, which was a fixed component of the rent package of customary land as a perpetual market adjustment compensating for low fixed rents. The levels charged steadily rose until the early fifteenth century, reflecting the buoyancy in the Cornish land market, but then declined subsequently. ${ }^{121}$ Even in the boom years, some individual contributions to the tallage were not collectable, such as the 49s. 2d. from diverse tenants of Tywarnhaile (Cornwall) who in 1400-1 were deemed too 'indigent and poor' to pay. ${ }^{122}$ In addition to this assessionable tallage, Duchy officials occasionally imposed a one-off recognition fine at the beginning of some seven-year periods, such as in $1381,1441,1458$ and 1461 , although the sums varied markedly from manor to manor. ${ }^{123}$ The precise reason, and justification, for these recognition fines are unclear. For example, in 1399 the collection of a $£ 89 \mathrm{~s}$. $8 \mathrm{~d}$. recognition fine at Liskeard (Cornwall) was postponed the following year after the tenants announced that those 'of the manor of Helston-in-Kirrier, and all of the manors in the county of Cornwall, had declined to pay such recognition because it is not accustomed, as they say'. ${ }^{124}$ In 1418 John Kelebrey, the reeve of Climsland (Cornwall), still owed f6 0s. 7d. in arrears for an earlier recognition fine which had proved uncollectable. ${ }^{125}$

Tallage often disappeared informally: landlords simply made a decision not to impose it, because they judged that otherwise they would lose tenants or face opposition. Similarly, liability to tallage was also dropped from many of those customary holdings converted from hereditary villein tenure to fixed-term tenancies for money rent, such as leases and life tenancies. ${ }^{126}$ A virgate at Shifford (Oxfordshire) on service tenure owed recognition to the abbot of Eynsham, but the liability disappeared for good when it was converted to a cash rent. ${ }^{127}$ In 1433 a customary holding in

\footnotetext{
117 Bailey, Decline of Serfdom, p. 288.

118 Page, Crowland Abbey, pp. 105-6, 309-12; TNA SC6/872/9 (Stevenage, Westminster abbey manor).

${ }^{119}$ No tallage is recorded at Berkswell, Budbrooke, Erdington, Lightern or Morton. $f 6$ 13s. 4d. was paid at Brayles, 40s. at Tonneworthe, and 3s. 4d. at Sutton, R.H. Hilton, ed., Ministers' Accounts of the Warwickshire Estates of the Duke of Clarence, 1479-80, Dugdale Society Publications, xxi (1964), pp. 33, 54, 74.

${ }^{120}$ In 1435-6 annual tallage of bond tenants was still being paid on the Richmond manors of Swaffham (Norfolk) and Bassingbourne (Cambs.), TNA SC6/944/13; Fryde, Peasants and Landlords, pp. 274-5.

121 Hatcher, Duchy of Cornwall, pp. 61, 148-65.

122 TNA SC6/819/10.

${ }^{123}$ Hatcher, Duchy of Cornwall, pp. 158, 160; TNA SC6/818/9 and SC6/821/11.

124 TNA SC6/819/10.

125 TNA SC6/820/8.

${ }^{126}$ Kanzaka, 'Villein Rents', pp. 616-7; Bailey, 'Transformation', pp. 226-8.

${ }^{127}$ H. F. Salter, ed., The Cartulary of the Abbey of Eynsham, Volume II, Oxford Historical Society, li (1908), pp. 78.
} 
Cobham (Surrey) was granted for money rent 'quit of tallage and all servile customs', while a similar grant included an additional $12 \mathrm{~d}$. rent per annum explicitly to compensate for the formal removal of tallage. ${ }^{128}$ Dropping tallage undoubtedly increased the attractiveness of customary land in the sharpened competition of the land market after the Black Death, because by reducing the rent levels and discarding a powerful symbol of servility it raised the dignity of customary land and, by extension, its attractiveness to non-villeins at a time when tenants were in short supply. Occasionally, tallage was removed through a more formal process, such as a collective agreement with all customary tenants as part of a wholesale restructuring of rent on the manor. For example, the annual Easter tallage on the Ramsey abbey estates was dropped formally in 1413 as part of a general restructuring of villein rents, and annual tallage disappeared from Kibworth Harcourt in 1427 after negotiations over the rent package of customary land. ${ }^{129}$

The decision to abandon tallage sometimes followed resistance to its collection among tenants, and resentment is most evident on the minority of manors where tallage persisted into the fifteenth century. In 1433 the bishop of Worcester's attempt to impose recognition at the rate levied in 1302 provoked widespread refusal: a further attempt to revive the levy in 1444 also failed, and by the 1450 s tenants were resisting annual tallages too. ${ }^{130}$ Likewise, resistance to recognition is recorded from mid-century on the estate of the Archbishop of Canterbury. ${ }^{131}$

Opposition to tallage usually involved a mix of stratagems, not just a blunt refusal to pay. Both tenant and landlord could opt to test the bounds and strength of each other's resolve, mixing conflict with compromise as events unfolded. ${ }^{132}$ Tenants were sometimes slow to elect assessors, causing some landlords to confront the go-slow head on and others to give up. ${ }^{133}$ In this regard, the contrasting approaches to recognition on the abbatial and conventual estates of Bury St Edmunds abbey are instructive. Before the Black Death recognition had been routinely levied across all the abbey's lands, including from people who were not tenants or serfs of the abbey but who were resident within the Liberty of St Edmund. During the second half of the fourteenth century its collection shrank to just the abbot's own manors. Passive peasant resistance in the 1380 s certainly contributed to its abandonment on the manors of the cellarer and across the Liberty of St Edmund, although the abbey's officials must also have acknowledged the severe problems of collecting it from people who were not tenants of the abbey.

By the 1380s the collection of recognition across the estate of the abbey of Bury St Edmunds had narrowed from the whole of the Liberty of St Edmund to just the abbot's own manors, where opposition to its payment was widespread. For example, after 1389 serfs and customary tenants at Chevington (Suffolk) were perpetually reluctant and tardy payers of recognition to the abbot. They sometimes elected assessors in the manorial court to apportion and collect the money, but then paid slowly or partially, while on other occasions they refused to elect assessors: by 1470 they were openly and angrily refusing either to elect or to pay. ${ }^{134}$ This pattern of resistance is almost identical

\footnotetext{
${ }^{128}$ No editor, Chertsey Abbey Cartularies, Volume II, Surrey Record Society, xii (1958), pp. 90-1.

129 This was the Easter tallage on the Ramsey estates, which was the conventional form of tallage: the Michaelmas tallage, which was more akin to agistment payments, continued for longer, Neilson, Economic Conditions, pp. 72, 90; C. Howell, Land, Family and Inheritance in Transition. Kibworth Harcourt 1280-1700 (Cambridge, 1983), pp. 50-1.

${ }^{130}$ Fryde, Peasants and Landlords, 142-3, 176.

${ }^{131}$ M. E. Mate, 'Tenant Farming and Farmers: Kent and Sussex', in Miller, ed., Agrarian History, pp. 685-6.

132 Larson, Conflict and Compromise, pp. 13-27, 225-40.

133 Bailey, Decline of Serfdom, pp. 182-4, 191-2, 263.

${ }^{134}$ Bailey, Decline of Serfdom, pp. 181-2.
} 
to that adopted by the tenants of the abbot's nearby manor of Hargrave (Suffolk), which indicates some planned resistance across some or all of the abbot's estate. Recognition due from Hargrave in 1389 was still partially owing in 1394; that from 1415 was not paid until 1419 following chivvying from estate officials; and in 1447, 1471 and 1476 the customary tenants of both manors refused outright either to elect assessors or to pay recognition. ${ }^{135}$ Thus successive abbots of Bury St Edmunds were doggedly persistent in their attempts to impose recognition upon these two abbatial manors throughout the fifteenth century, but they failed to raise a penny after the 1440s in the face of coordinated resistance. The abbots' persistence was a pedantic assertion of an ancient custom, not a realistic policy or aspiration. The opposition to its payment was probably stiffened by the changing status of customary tenants, many of whom were freemen and incomers holding villein land on fixed-term leases, rather than hereditary serfs holding tenure in villeinage, who would have been especially sensitive to paying an archaic incident with overt trappings of servility.

Other landlords adopted a less confrontational approach to recognition, rather than stubbornly insisting upon its payment at the old level for decades, initially through proactive reductions in the amount to be paid, and then by pragmatically abandoning it when its collection had become impossible. This 'managed retreat' characterised the approach of the estate of the prior of Ely. His tenants of Winston (Suffolk) had paid 53s. 4d. in the 1340s upon the election of a new prior, but in 1366 this was reduced to 33s. $4 \mathrm{~d}$. 'by the lord's special grace'. ${ }^{136}$ The only hint of opposition to its payment occurred in 1425 , when the call for recognition was made in the new prior's second court held in October, rather than the usual practice of his very first court in June. In June the tenants had been given until the following Tuesday to appear in front of the steward of the estate at Barham (Suffolk) 'to establish reasons why they should not render payment to the lord prior of Ely as in the past' ${ }^{137}$ The requirement for tenants to travel to Barham to voice their objections looks a canny move, because Barham was the most westerly and isolated of the prior's cluster of manors in east Suffolk. ${ }^{138}$ Hence the prior was providing his customary tenants with an opportunity to voice their concerns through a due process, but he was subtly testing the strength of their resolve to resist by selecting the most inconvenient and inaccessible manor. Nothing more is recorded about the matter, but when recognition was next levied in 1432 the sum had been further reduced to 20s. "by special grace'. It was not levied thereafter. No mention was made of recognition in 1462 on the election and first court of prior Henry Peterborough. ${ }^{139}$ By adopting a policy of managed retreat the prior faced less overt resistance from his tenants to the payment of recognition than the abbot of St Edmunds experienced through stubborn and dogged intransigence.

\section{4}

A clearer understanding of how tallage-at-will operated on the ground also reveals a good deal about contemporary attempts to separate villeinage from freedom. From the 1220 s lawyers sought increasingly to distinguish tallage-at-will from other forms of tallage as part of a wider movement to

\footnotetext{
${ }^{135}$ SROB E3/15.10/1.19, courts held November 1389 and October 1394; E3/15.10/1.22, courts held October 1415 and September 1419; E3/15.10/1.24, court held May 1447; E3/15.10/1.2, courts held May 1471 and November 1476.

${ }^{136}$ CUL EDC 7/19/20, court held January 1366.

${ }^{137}$ CUL EDC 7/19/46, courts held June and October 1425.

${ }^{138}$ M. Bailey, Medieval Suffolk. An Economic and Social History c.1200-c.1500 (Woodbridge, 2007), p. 17.

${ }^{139}$ CUL EDC 7/19/49, court held October 1432; 7/19/62, court held June 1462.
} 
differentiate the dues imposed on free land from those on customary land, so that reliable tests of villeinage could be established under the common law. ${ }^{140}$ The separation of free from unfree tallage was also promoted as part of contemporary social rhetoric. ${ }^{141}$ Thirteenth-century lawyers advised pleaders to emphasise the uncertainty of the timing and level of servile tallage, in contrast to the certainty of the aid paid by freemen. ${ }^{142}$ Free aid was held to be both consensual and certain, because it was paid from the grace and good will of the tenant (de bone voluntate) and not as part of the services attached to the land, whereas uncertain servile tallage was paid at the will of the lord (ad voluntatem domini) as part of the services of the tenement, and so in legal theory could be varied at any time. ${ }^{143}$ This legal argument has also influenced the views of some modern historians, who contend that uncertainty formed a central and unwelcome political dimension to the nature of villein rent. ${ }^{144}$ They argue that even though servile tallage had acquired many fixed and stable characteristics, and even though its economic demands were not exorbitant, the lord still had the potential to make an arbitrary, exorbitant and unjust action, which was both unsettling and a source of resentment: the villein had to live constantly with 'the nagging fear...that a lord would make an abrupt demand'. ${ }^{145}$ Consequently, it was a stigmatic and demeaning incident.

Medieval lawyers might attempt to carve a clean legal separation between free aid and servile tallage, but a clean separation had to exist in practice as well as in the minds of theorists if tallage was to serve as an effective test of villeinage. In reality, the distinction was blurred in too many places, as implied by the absence of a strict semantic distinction between a 'free aid' and a 'servile tallage'. A major difficulty was that on some manors both free and unfree peasants owed the same tallage. ${ }^{146}$ The liability of freemen and villeins for the same tallage is implied in the use of phraseology that consciously avoided the vocabulary of villeinage (such as auxilium de ville and commune tallagium). Thus in 1270 the 'people' (homini) of both Great and Little Coxwell (Berks.) paid recognition to the abbot of Beaulieu, implying payment from a wider constituency than just the villeins; in 1289 tallage at Bedlow (Bucks.) was payable by all tenants (tallagium ville videlict tenentium domini); and the vill rather than the manor rendered tallage on many Bec abbey manors. ${ }^{147}$ In 1279 recognition payments upon the election of John of Northwold as abbot of Bury St Edmunds included free tenants. ${ }^{148}$ For example, 95 s. was raised from the customary tenants (de recognitione de customariis) of Cheppenhall manor and a further 15s. from its free tenants (de libere tenentibus). ${ }^{149}$ Even a local knight, Sir Eustace de Berningham, contributed. ${ }^{150}$ The whole homage of the vill (i.e. not just the manor) of Hargrave (Suffolk) was liable, which explains why the collection of recognition was handled through the leet not the manor court. ${ }^{151}$ Recognition was even due from vills which did not contain demesne manors of the abbey but lay within the Liberty of St Edmund,

\footnotetext{
140 Hyams, King, Lords and peasants, pp. 190-1.

${ }^{141}$ Scase, Literature and Complaint, pp. 17, 26.

142 Pollock and Maitland, History of English Law, I, p. 350; Hyams, King, Lords and Peasants, pp. 191-3.

143 Pollock and Maitland, History of English Law, I, pp. 350, 391, 393; Hyams, King, Lords and Peasants, p. 195.

144 P. Freedman, Images of the Medieval Peasant (Stanford, 1999), pp. 83-4, 240; Hilton, Class Conflict, p. 51;

Dyer, 'Ineffectiveness', p. 86.

145 Dyer, 'Villeins, Bondsmen', p. 428.

${ }^{146}$ Howell, Regalian Right, pp. 138-9; Levett and Ballard, The Black Death, p. 195; Miller, Bishopric of Ely, p. 140

n. 3; R. DuBoulay, The Lordship of Canterbury. An Essay on Medieval Society (London, 1966), p. 181.

147 Hockey, Account Book of Beaulieu Abbey, pp. 89-90; Maitland, Select Pleas, pp. 10-11, 33.

148 Pinchbeck Register, I, pp. 468: for example, de recognitione de Pakenham cum libere tenentibus.

149 Pinchbeck Register, I, pp. 467-9; BL, Harl. Ms. 230, f. 62.

150 Pinchbeck Register, I, p. 469.

${ }^{151}$ SROB, E3/15.10/1.23, court held May 1429; and E3/15.10/1.24, court held December 1445.
} 
and therefore was paid by men who were not even the abbey's tenants. ${ }^{152}$ Recognition applying to both free and unfree was probably an unreformed version of tallage reaching back to its origins in the eleventh century. ${ }^{153}$

The intertwining of free and servile tallage in this manner underlines the point that attempts to segregate the two were driven primarily by legal imperatives from above. ${ }^{154}$ The difficulties faced by the legal theorists are also reflected in the hollowness of their claim that free aid was consensual whereas servile tallage was compulsory. Legal historians have dismissed the notion of consensual aid as unconvincing legal 'theory', and political historians have wondered why lords and freemen complained so frequently about the regularity and weight of royal aid if they had truly consented. ${ }^{155}$ In fact, prior consent was seldom sought or obtained for royal aids, which therefore had 'the force of a command' and were effectively levied by the 'mere will of the king'. ${ }^{156}$ Harriss observed that 'there was probably little that was voluntary about them', and Warren considered that 'a gracious aid was little different from a tyrannous imposition'. ${ }^{157}$ Indeed, in the spirit of Warren's observation it could be argued that John's royal aid of 1207 , which raised the 'stupendous' sum of $£ 60,000$ from the subjects of the realm, is the best example of an arbitrary tallage in the whole of the Middle Ages: it was onerous, imposed and unexpected. ${ }^{158}$ In short, English kings of the twelfth and thirteenth centuries levied aid by prerogative without prior counsel or consent, although the amount they charged was tempered by some bargaining and the force of custom. ${ }^{159}$

Thus a monarch who pleaded necessity for aid took the consent of his leading subjects for granted and obliged them to pay it: they might negotiate the sum, but they could not refuse. ${ }^{160}$ This principle descended the social scale from tenants-in-chief to their vassals and free tenants, who were also liable to aid when their lord paid tallage or relief to the king and could not refuse. Even the liability of free tenants for additional aids on specified occasions within the life cycle of their lords, such as knighthood of the eldest son or the marriage of the eldest daughter, was fixed and did not require consent. ${ }^{161}$ Thus in every practical sense royal and freemen's aids were non-negotiable, in much the same way as villein's aid. They were assessed on property, too, similar to servile aids. ${ }^{162}$ For example, in 1328 free tenants of the manor of Cornard Parva (Suffolk) contributed an aid assessed at a fixed rate in proportion to their landholding. ${ }^{163}$ So when free aid is described as 'consensual', it did not mean that the king or the lord required prior approval from his subjects, or that a lord or free tenant could refuse a specific request: it meant that in return for aid the king or

\footnotetext{
152 Described as recognitiones et auxilia gersummariorum in hundredis Abbatis. The vill (villata) of Boxford paid 20s., and the payment from Icklingham explicitly included free tenants, even though neither place contained any demesne manor of the abbey, Pinchbeck Register, I, pp. 467-8.

153 Stephenson, 'Seignorial Tallage', pp. 467-8, 472-3; Neilson, 'Customary Rents', pp. 91, 93.

154 Hyams, King, Lords and Peasants, p. 191.

155 Pollock and Maitland, History of English Law, I, p. 350; Howell, Regalian Right, pp. 124-5; Scase, Literature and Complaint, pp. 17, 26.

${ }^{156}$ Harriss, King, Parliament, p. 41; Mitchell, Studies in Taxation, p. 247; Hoyt, Royal Demesne, p. 108.

${ }^{157}$ Harriss, King, Parliament, p. 12; W. L. Warren, King John (Yale, 1997), p. 167.

158 D. A. Carpenter, Struggle for Mastery: Britain 1066-1284 (London, 2003), p. 272.

159 Harriss, King, Parliament, p. 14.

${ }^{160}$ Idem, pp. 17-26.

${ }^{161}$ Pollock and Maitland, History of English law, I, pp. 349-50; Stephenson, 'Seignorial Tallage', p. 466; S. F. C. Milsom, The Legal Framework of English Feudalism (Cambridge, 1976), pp. 26, 33.

162 Mitchell, Studies in Taxation, p. 351.

${ }^{163}$ Vinogradoff, Villeinage, p. 163.
} 
lord was obliged to receive counsel from, and to engage in a dialogue with, their dependents. ${ }^{164}$

Finally, the legal distinction between the 'certainty' of free aid and the 'uncertainty' of unfree aid is open to challenge. Servile tallage is held to have been uncertain in two ways: the frequency and/or quantum of annual tallage could be changed at the lord's will, and the timing of recognition was not fixed but 'depended on the accident of death and succession' of the lord. ${ }^{165}$ But, as we have seen, in reality the frequency and quantum of tallage-at-will was largely fixed, and thirteenth-century justices in the royal courts were not convinced that servile tallage could be charged 'high and low' on demand. ${ }^{166}$ They recognised that villein dues and rents had become largely ossified though custom and practice, and were seldom altered arbitrarily. When medieval lawyers argued that villein dues were 'uncertain and indeterminate', they were well aware that in reality there was little uncertainty about their frequency or duration. ${ }^{167}$ A close reading of the work of the most important contemporary authority-Bracton-reveals that the legal argument about the uncertainty of villeinage only appears within one specific context, when contrasting the privileged villeinage of the royal demesne with the pure villeinage of all others. Bracton's point was that villeins on the royal demesne had some protection against ejection and rent increases, whereas all other villeins did not: their tenure was uncertain in the sense of not having any legal redress within the common law. ${ }^{168}$

Tallage-at-will was no more or less uncertain or unpredictable than free aids. Indeed, as the levy of a royal aid in the mid-thirteenth century was dependent upon political and military circumstances which fluctuated unpredictably, and whose nature varied in gravity, then we might argue that its frequency, timing and quantum were less predictable than an annual tallage-at-will. Similarly, the villein who did not know when a new lord might accede to the manor, and therefore did not know when recognition might be payable, faced no more uncertainty than the freeman who owed aid when his lord's eldest son was knighted. Both knew the occasions when it would be liable, although neither could be certain of the exact timing. This aspect of free aid was just as certain or, if one prefers, just as uncertain, as servile recognition.

The blurring of the differences between free and servile aid-both in theory and on the groundemphasizes the limitations of the legal attempt to impose a clear distinction between them from above. ${ }^{169}$ Free aid was no more consensual than servile tallage, in the sense that neither freeman nor serf was consulted in advance and neither could refuse to pay. Likewise, free aid was no more certain than tallage-at-will, in the sense that both its frequency and level were liable to change. As a result of this blurring, tallage-at-will was no more than good corroborative evidence as a test of villeinage in common law, and cases where the evidence turned on it alone were rare. ${ }^{170}$ During the course of the thirteenth century landlords began to record transfers of customary land systematically in manorial court rolls, using standardized and carefully selected vocabulary, which provided reliable written proof of villein land that gradually superseded tallage. ${ }^{171}$

\footnotetext{
164 Harriss, King, Parliament, pp. 20-2, 29-39.

${ }^{165}$ Dyer, 'Ineffectiveness', pp. 74, 86. The quote is from p. 74.

${ }^{166}$ Hyams, King, Lords and Peasants, p. 191

${ }^{167}$ Hatcher, 'English Serfdom', p. 9.

${ }^{168}$ Hyams King, lords and Peasants, pp. 194-5.

169 Hatcher, 2015, pp. 114-15; Hyams King, lords and peasants, p. 191.

170 Idem, p. 191.

${ }^{171}$ R. M. Smith, 'Some Thoughts on 'Hereditary' and 'Proprietary' Rights in Land under Customary Law in Thirteenth and Early Fourteenth Century England', Law and History Review, xcv (1983), pp. 106-12; L. A. Slota, 'Law, Land Transfer and Lordship on the Estates of St. Albans Abbey in the Thirteenth and Fourteenth Centuries', Land History Review, Ixix (1988), pp. 121-3; Z. Razi and R. M.
} 
The one substantive difference between free and unfree tallage is that in the event of a dispute the freeman possessed two realistic mechanisms for redress. First, freemen-from magnates, to local lords and free peasants-could insist upon opportunities for providing counsel in return for rendering aid, whereas the villein could not. ${ }^{172}$ Second, freemen could seek redress in the royal courts in the event of a dispute over tallage with their lord, whereas the villein could not, and after 1275 the level of free aids was capped by statute, whereas servile tallage was not. ${ }^{173}$ The serf's only options were to resist or to try and access the royal courts by claiming royal demesne. So when nobles, freemen and lawyers argued that their aid was granted consensually, they did not mean that it was negotiable, and when they argued that it was certain, they did not mean that it was predictable. They meant that the right to receive counsel and to access the king's courts provided them with some protection against seigniorial interference. The uncertainty of servile tallage was uncertain principally in the sense that the villein had no legal mechanism for redress in the event of a dispute. Therefore tallage-at-will was socially stigmatic, because it symbolised the villein's exclusion from the royal courts in matters of tenure and status.

5

Tallage in various forms was applied to all sections of twelfth- and thirteenth-century English society, and by the 1240 s tallage-at-will had become firmly established as a prerogative tax on villeins and a test of villeinage under the common law. Contemporary lawyers argued that it was compulsory and uncertain, which has led many historians to portray it as a variable, exorbitant, arbitrary and unpredictable component of villein rent. This survey reveals, however, that by c.1300 it was neither arbitrary nor unpredictable, and instead its frequency and quantum had become codified and largely fixed along with all the other elements of the villein rent package. Its timing and rates were heavily influenced by custom; the manorial community was sometimes directly involved in determining how it was allocated; and the liability of any one villein was capped. Consequently, its frequency was fixed and its sum usually fluctuated within known margins around an established level. The form and operation of tallage-at-will had become codified, and any seigniorial attempts to treat it otherwise were likely to provoke resistance and conflict. ${ }^{174}$

The variety in the form and operation of tallage from manor to manor is striking, and emphasizes the influence of custom in its operation. It was not levied on all manors, especially those held by lesser landlords. It was levied as an annual charge on some manors, as an occasional recognition of a new lord on others, and sometimes as both. Even on manors where it was due, tallage was not charged in some years. The extent to which it added to the burden of villein rent therefore varied markedly. Methods of determining individual contributions varied too. Such variations are evident even within an estate held by the same landlord. Thus the example of tallage-at-will serves to reinforce the heterogeneity of villeinage in England and, by extension, the unevenness of its

Smith 'The Origins of the English Manorial Court Roll as a Written Record', in Z. Razi and R. M. Smith, eds., Medieval Society and the Manor Court (Oxford, 1996), pp. 53-4; P. R. Hyams, 'What did Edwardian Villagers Understand by Law?', in Razi and Smith, eds., Medieval Society, pp. 81-2. 172 Hyams, King, Lords and Peasants, p. 198.

${ }^{173}$ Pollock and Maitland, History of English Law, I, p. 350-1; Milsom, Legal Framework, pp. 26, 33

${ }^{174}$ Hatcher, 'English Serfdom', pp. 19-21; Campbell, 'Agrarian Problem', pp. 24, 65, 69; Dyer, 'Ineffectiveness', pp. 79-81. 
experience on the ground. ${ }^{175}$ The unevenness of villeinage mattered little in the land-hungry years around 1300 , but became especially significant after the collapse of population in the Black Death, because it accentuated the competition among lords for scarce tenants, especially land-deficient free tenants seeking to augment their meagre free holdings by acquiring customary land. If villeinage had been more uniform and standardised in its form and operation, then lords would have found it much easier to dampen competition for tenants after the Black Death and to coerce tenants to hold servile land market on terms favourable to lords.

The absence of tallage-at-will from a sizeable minority of manors in c.1300, and its rapid decline and disappearance after 1348-9 from many more, undermines its significance as one of the two key tests of villeinage in the common law. In the first half of the thirteenth century lawyers promoted tallage-at-will as a test of villeinage, when they were seeking to accentuate the gap between servile and free obligations. At this date tallage served as a useful test in legal cases of villeinage, usually as corroborative evidence in tenurial disputes, but thereafter its usefulness declined. ${ }^{176}$ During the second half of the thirteenth-century estate administrators developed a body of documentationmainly within manorial court rolls and surveys - that maintained a rigorous, formal and standardized record of customary land and so provided better legal proof of the status of villein land than tallage. During the course of the thirteenth century the rise of local written records as the basis of precedent and proof in legal cases diminished the legal significance of tallage-at-will, just as the codification of villein rents reduced its economic potency. Yet it remained a powerful symbol of the exclusion of villeinage from the royal courts, and as such perpetuated the social stigma of attached to tenurial unfreedom.

175 Bailey, 'Villeinage in England', pp. 22-6.

176 Hyams, King, Lords and Peasants, pp. 191-4. 